\title{
Recharge observations indicate strengthened groundwater connection to surface fluxes
}

Wouter R. Berghuijs ${ }^{1 *}$, Elco Luijendijk ${ }^{2}$, Christian Moeck ${ }^{3}$, Ype van der Velde ${ }^{1}$, Scott T. Allen ${ }^{4}$

1. Department of Earth Sciences, Free University Amsterdam, Amsterdam, Netherlands.

2. Bundesgesellschaft für Endlagerung, Eschenstraße 55, 31224, Peine, Germany.

3. Eawag - Swiss Federal Institute of Aquatic Science and Technology, Department Water Resources and Drinking Water, Dübendorf, Switzerland.

4. Department of Natural Resources and Environmental Science, University of Nevada, Reno, Reno, USA.

*Contact: $\quad$ w.r.berghuijs@vu.nl 
Groundwater is an invaluable global resource, but its long-term viability as a resource for consumption, agriculture, and ecosystems depends on precipitation recharging aquifers (Alley et al., 2002; Gleeson et al., 2012). How much precipitation recharges groundwaters varies enormously across Earth's surface (Scanlon et al., 2006; Moeck et al., 2020; MacDonald et al., 2021; Müller Schmied et al., 2021), but recharge rates are uncertain because field observations are sparse and modeled global estimates remain largely unvalidated (Döll and Fiedler, 2008; de Graaf et al., 2015, 2019; Mohan et al., 2018; Müller Schmied et al., 2021; Li et al., 2021). Here we show that recharge is predictable as a simple function of climatic aridity - the ratio of long-term potential evapotranspiration to precipitation - using a global synthesis of measured recharge of 5237 sites across six continents. We use this relationship to estimate long-term recharge globally outside of permafrost regions. Our estimates double previous global estimates (Döll and Fiedler, 2008; de Graaf et al., 2015, 2019; Mohan et al., 2018; Müller Schmied et al., 2021) and are more consistent with empirical observations. These revised higher estimates of global groundwater recharge imply that much more groundwater must contribute to evapotranspiration and streamflow than previously represented in global water cycle depictions (Oki \& Kanae, 2006; Abbott et al., 2019; Dorigo et al., 2021) or global hydrological and Earth system models (Reinecke et al., 2021; de Graaf et al., 2015, 2019; Müller Schmied et al., 2021; Döll and Fiedler, 2008).

Groundwater constitutes almost all of Earth's liquid freshwater (Gleeson et al., 2016; Abbott et al., 2019) and is the world's most extracted raw material, with global withdrawals estimated at almost one thousand cubic kilometers per year (Margat \& Van der Gun, 2013; Döll et al., 2014; Sutanudjaja et al., 2017). It provides approximately two billion people with drinking water (Morris et al., 2003) and supplies almost 40\% of irrigated lands worldwide (Siebert et al., 2010). Groundwater also shapes ecosystems and landscapes as rivers and vegetation can source their waters from aquifers (Jasechko et al., 2016; Evaristo \& McDonnell, 2017; Berghuijs \& Kirchner, 2017; Fan et al., 2017).

The dynamic roles of groundwater are not always apparent, but for groundwater to sustain ecosystems and water resources into the future, aquifers must be recharged (Alley et al., 2002; Gleeson et al., 2012). Earth's diversity of landscapes and climates results in groundwater recharge rates that vary by orders of magnitudes globally (Gee \& Hillel, 1988; Scanlon et al., 2006; Moeck et al., 2020; MacDonald et al., 2021). Yet, for most of Earth's 
surface, groundwater recharge rates are uncertain because measurements are sparse (Scanlon et al., 2006; Moeck et al., 2020), and large-scale modeled recharge remains mostly unvalidated (Li et al., 2021, Reinecke et al., 2021). In addition, upscaling recharge estimates derived from extensively studied sites to other locations is challenging because many landscape and surface properties can affect recharge (De Vries \& Simmers, 2002; Crosbie et al., 2018; Moeck et al., 2020). These issues are problematic because accurate recharge estimates are needed to assess the sustainability of groundwater use and the role of groundwater in supporting ecosystems and surface waters (Gleeson et al., 2020).

Here we show that climate aridity (Trabucco \& Zomer, 2009) - the ratio of potential evapotranspiration to precipitation - strongly controls the fraction of precipitation that becomes groundwater and use this relationship to estimate global recharge rates. We parameterize a function capturing this relationship using a synthesis of 5237 groundwater recharge measurements from all continents except Antarctica, with recharge defined as the infiltrated water reaching the water table (Moeck et al., 2020) (see Methods). We show that this simple parameterization outperforms complex simulation models in predicting recharge across the globe. Not only are our resulting estimates more consistent with the aforementioned groundwater recharge measurements, but they also support groundwater recharge estimates that are more than twice as high as most previous global estimates (Döll and Fiedler, 2008; de Graaf et al., 2015, 2019; Mohan et al., 2018; Müller Schmied et al., 2021).

\section{Climate aridity shapes groundwater recharge}

The empirical recharge values from sites spanning most regions of the globe (Moeck et al., 2020) show that recharge fractions are strongly controlled by climate aridity (Fig. 1), despite many other factors also affecting groundwater recharge globally (De Vries \& Simmers, 2002; Taylor et al., 2013; Moeck et al., 2020). In humid climates, typically, larger fractions of precipitation recharge groundwater. This recharge fraction shrinks with increasing aridity, often approaching almost zero in very arid sites. This relationship is nonlinear, and the empirical data show substantial variation for a given aridity, reflecting an influence of other environmental conditions. However, the pattern is sufficiently monotonic to yield a highly significant correlation between climate aridity and the fraction of precipitation that recharges groundwaters (Spearman $\rho=-0.674 ; p<0.001$ ). This relationship is consistent with past work, which indicated that both precipitation and potential evapotranspiration can strongly affect 
groundwater recharge (Gee \& Hillel, 1988; Scanlon et al., 2006; Moeck et al., 2020; MacDonald et al., 2021).

The vast majority (i.e., 99\%) of the empirical recharge values (Moeck et al., 2020) are from regions with climate aridities exceeding 0.75 . These aridities cover most of Earth's surface aside from Earth's wettest regions (e.g., Congo Basin, Amazonia, Southeastern Asia), which largely fall outside the observational range. The empirical data (Fig. 1b) suggest recharge fractions can shrink again at very low aridities, but this remains uncertain because only $1 \%$ of the recharge-measurement sites had aridities below 0.75 . In addition, the sites fall outside of permafrost regions (Obu et al., 2019), where recharge processes often differ from nonpermafrost regions (Walvoord \& Kurylyk, 2016). We, therefore, suggest that the empirical climate-recharge pattern are likely representative for large parts of Earth's surface, but how recharge in very humid and permafrost regions evolves with aridity cannot be directly predicted with the existing data.

Much of the variations in recharge fractions can be described by a sigmoidal function of climate aridity (Methods) (Fig. 1b). Calibrated on all data (see Methods), this function describes how recharge exceeds $50 \%$ of precipitation $(\alpha=0.72)$ when aridity approaches one (i.e., precipitation equals potential evapotranspiration), and decreases with increasing aridity ( $\beta=15.11)$. It succeeds in capturing a strong global trend of groundwater recharge decreasing with aridity. The relationship is least constrained at low aridities, where both high and low recharge rates can occur. Although this parameterization is simple, it captures the observed global trend in the fraction of precipitation that becomes groundwater recharge much more accurately than widely-used global hydrological models (Döll and Fiedler, 2008; de Graaf et al., 2015, 2019; Mohan et al., 2018; Müller Schmied et al., 2021), which underestimate recharge in both arid and humid regions (Fig. S1). The parsimony of our model (Fig. 1b) could hypothetically limit its predictive power, but using more predictor variables does not substantially improve its predictive capacity (Methods and Fig. S2). A split-sample test using $80 \%$ of the data for calibration and the remaining $20 \%$ for validation yields relatively narrow confidence bounds of the fitted parameters $(95 \%$ confidence intervals $\alpha=0.69-0.75, \beta=14.0-16.2$ (not displayed)), thus also subsets of the empirical data effectively constrain the relationship (Fig. S2 and Methods). Therefore, predictions of 
groundwater recharge based on climate aridity appear effective despite excluding many other factors that may also affect groundwater recharge.
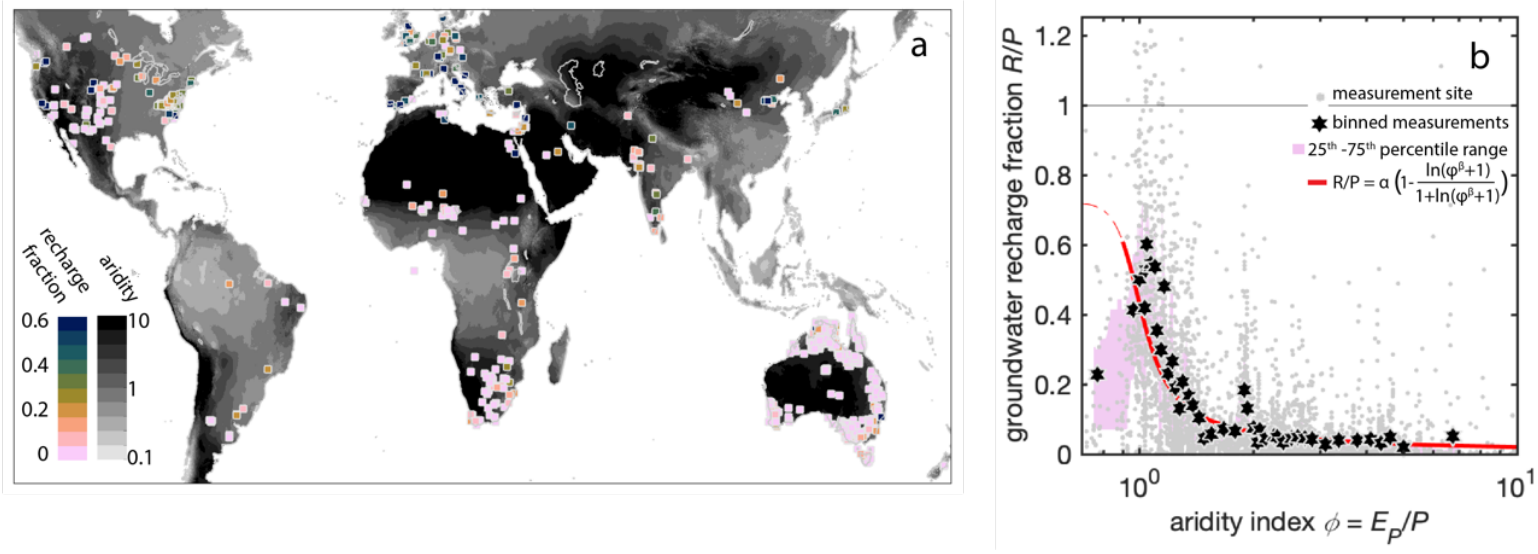

Fig. 1. Groundwater recharge fractions vary with aridity. Recharge fractions (the ratio between long-term recharge and long-term precipitation) at the 5237 sites and the global pattern of climate aridity (a), whereby recharge negatively correlates with aridity (b). The grey markers indicate the recharge fractions of individual groundwater recharge sites, whereas dark markers average across $2 \%$ of the sites, removing most local site-tosite variability. The pink shading indicates a $25^{\text {th }}-75^{\text {th }}$ percentile over 100 data points. The red line depicts the calibrated sigmoid function Eq. 1.

\section{Global pattern of recharge}

The parameterized relationship between climate aridity and recharge fraction (Eq. 1; Fig. 1b) enables estimating the global distributions of groundwater recharge fractions (Fig. 2a) and total groundwater recharge (Fig. 2b) using global aridity and precipitation data (Trabucco \& Zomer, 2009; Fick \& Hijmans, 2017) (see Methods). The estimated global pattern of groundwater recharge fractions shows large regional differences in how much precipitation recharges groundwater, broadly consistent with the dataset comprising observations from the 5237 sites (Fig. 2a; Fig. 1b). We exclude permafrost regions (see Methods) because the 5237 sites with recharge data are not located within permafrost regions. In addition, places with aridity below 0.75 are shaded gray in Figure 1 to indicate that estimates in these regions are poorly constrained by the empirical climate aridity function.

Estimated groundwater recharge fractions are low $(<0.1)$ across roughly half of Earth's surface (excluding permafrost regions) (Fig. 2a), as drylands are very prevalent across all continents but Europe (Fig. 1a) (Berg \& McColl, 2021). Recharge fractions increase across more humid parts of Earth such as most of Europe, eastern North America, central Africa, Southern Asia, and most of South America. These regional patterns are both present in 
observations (square markers) and the estimated global pattern (background coloring). Absolute recharge rates show largely similar regional patterns (Fig. 2b), but the differences in estimated recharge are even greater between humid and arid regions. Estimated recharge would be highest in the equatorial wet regions and coastal regions of Central and North America, Europe, and Oceania (consistent with earlier global estimates (Döll and Fiedler, 2008; de Graaf et al., 2015, 2019; Mohan et al., 2018; Müller Schmied et al., 2021), but large parts of these areas have aridities below 0.75 which means recharge estimates are hard to constrain because few data exist at these locations. Nevertheless, even when recharge fractions are low, the potential of high absolute recharge rates will remain substantial in these regions as they experience high precipitation rates.
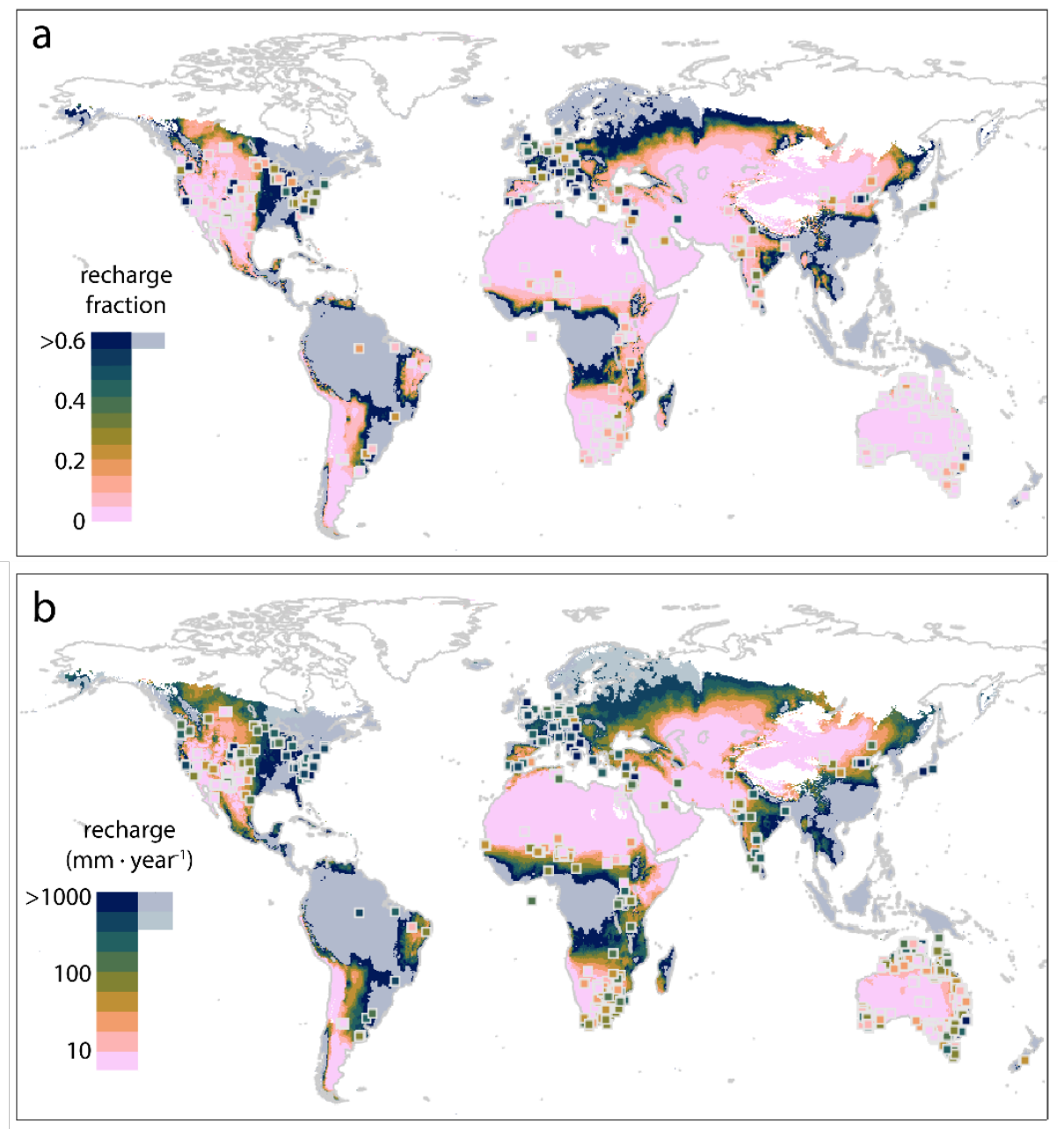

Fig. 2. Estimated global patterns of groundwater recharge outside of permafrost regions. Estimates of groundwater recharge fractions vary regionally (a) and are based on global climate data (Trabucco \& Zomer, 2009; Fick \& Hijmans, 2017) and Equation 1.. The absolute groundwater recharge values show high spatial variation because both the precipitation amount and the fraction of precipitation that becomes recharge are correlated with aridity (b) (note the logarithmic color scale). These groundwater recharge totals more than 
double most previous global estimates (Döll and Fiedler, 2008; de Graaf et al., 2015, 2019; Mohan et al., 2018; Müller Schmied et al., 2021). Markers indicate the observations at the 5237 sites. Permafrost regions are classified by having a mean annual temperature below $-2{ }^{\circ} \mathrm{C}$.

Our recharge estimate more than doubles most previous global estimates (Döll and Fiedler, 2008; de Graaf et al., 2015, 2019; Mohan et al., 2018; Müller Schmied et al., 2021) at the location of the recharge sites (Fig. 3; Fig. S3). Those previous global estimates have not been systematically evaluated with observed recharge data but rather with proxies such as streamflow measurements and groundwater levels. If we compare the modeled recharge rates from the widely-used PCR-GLOB (de Graaf et al., 2015, 2019) and WaterGAP (Doll and Fiedler, 2008; Müller Schmied et al., 2021) global hydrological models with the recharge observations at the 5237 sites, we find that these models underestimate observed groundwater recharge on average by more than 50\% (Fig. 3) for the observation sites. A similar but even more substantial bias is present in another global recharge estimate based on 715 sites with recharge data (Mohan et al., 2018) (Fig. 3). Split-sample tests do not show any such biases resulting from our empirical function (Fig. S2). An example realization of our model (Fig. S3f) shows how much better it explains observed recharge than other global hydrological models (Fig. S3a-e). The biases of these other hydrological models arise from underestimations at both high and low recharge rates. 


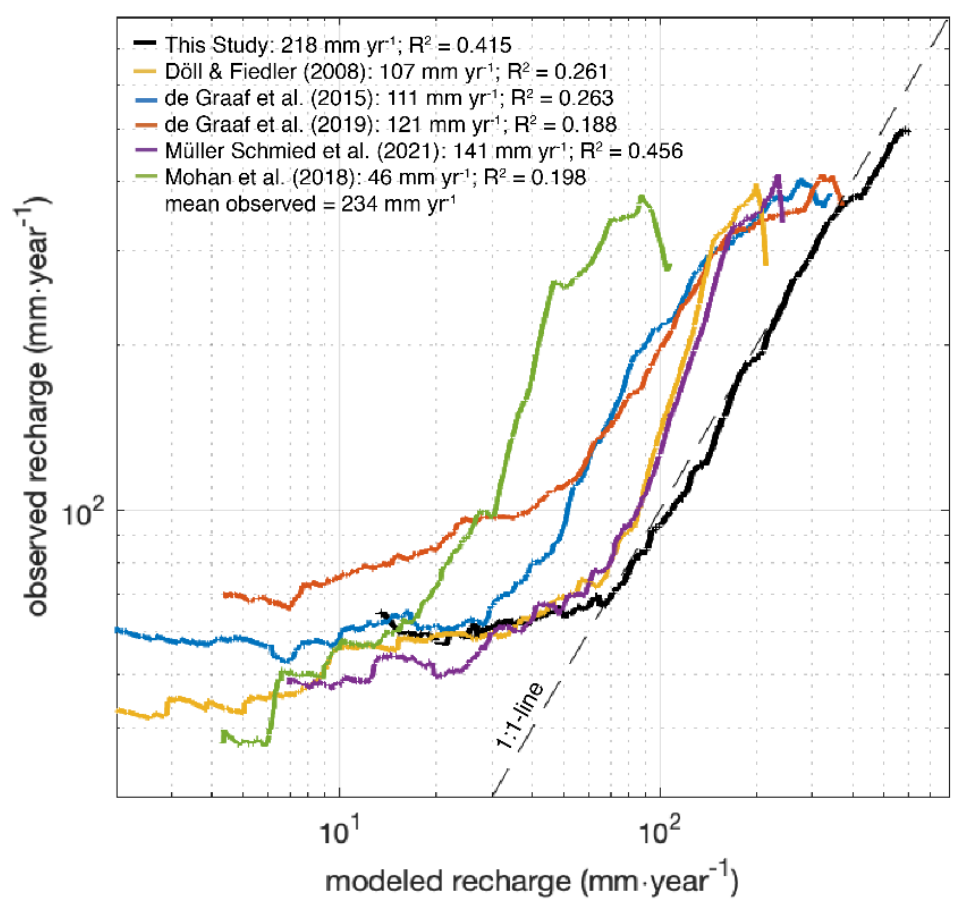

Fig 3. Comparison of predicted versus observed recharge for several global recharge predictions. Moving averages of recharge predicted by global models such as PCR-GLOB (de Graaf et al., 2015; 2019), WATERGAP (Döll et al., 2008; Müller Schmied et al., 2021), and machine learning (Mohan et al., 2018) are systematically lower than recharge of the 5237 observation sites. The predictions by global models underestimate recharge by more than 50\% compared to the recharge measurement (Moeck et al., 2020). Using the sigmoid function (Eq. 1) largely removes this bias and produces an overall average recharge of a very similar magnitude as global recharge estimates. The presented recharge rates are moving averages over $10 \%$ of the data. More detailed comparisons of modeled and observed recharge are presented in Fig. S3.

\section{Implications}

Aquifer storages are governed by the balance between recharge and discharge of groundwater to surface waters and vegetation, in addition to human abstractions (Alley et al., 2002). Our estimate of groundwater recharge more than doubles most previous estimates across where observations are available (Fig. 3; Fig. S3) and dwarfs global groundwater abstractions by roughly a factor of fifty (Margat \& Van der Gun, 2013; Döll et al., 2014; Sutanudjaja et al., 2017). This enhanced recharge does not counter the current understanding of regional groundwater overuse and its threats to global water security (Famiglietti, 2014) because groundwater overuse results in storage depletion and declining water levels that have been robustly documented in many more arid areas across the globe (e.g., Gleeson et al., 2012; Rodell et al., 2018). Instead, our recharge estimates imply that groundwater's role in 
evapotranspiration and surface water fluxes is much larger than previously modeled (Döll and Fiedler, 2008; de Graaf et al., 2015, 2019; Müller Schmied et al., 2021).

This implied greater role of groundwater in supplying streamflow and evapotranspiration is consistent with global observations that have shown that vegetation can source substantial parts of their water from groundwater and vegetation disproportionally occurs near zones where it can access groundwater as a water source (Evaristo \& McDonnell, 2017; Koirala et al., 2017; Fan et al., 2017). It is also consistent with the observation that most precipitation is stored in landscapes for at least several months before being observed in rivers (Jasechko et al., 2016) and suggests a vital role of groundwater for streamflow and aquatic ecosystems during dry periods. These dynamic connections with vegetation and streams likely predominantly occur in the upper layers of groundwater as deeper groundwaters mostly exchange slowly with the Earth's surface (Jasechko et al., 2017; Gleeson et al., 2016; Berghuijs and Kirchner, 2017).

Not only recharge but also its main potential fates (i.e., streamflow versus evapotranspiration) depend strongly on climate aridity (Budyko, 1974). How much of precipitation becomes streamflow shrinks with increasing aridity, whereas the evaporative fraction grows with increasing aridity (Budyko, 1974) (Fig. 4). In humid areas, which typically have substantial recharge, both streamflow and evapotranspiration will have groundwater contributions as streams typically have water levels below adjacent groundwaters (Jasechko et al., 2021). However, recharge tends to exceed typical streamflow rates (Fig. 4). Losing rivers are more common in drier climates (Jasechko et al., 2021), suggesting a smaller role for recharge in their streamflow and probably more recharge ultimately going to evapotranspiration. The relative contribution of groundwater for transpiration is also reported to grow with aridity (Evaristo \& McDonnell, 2017) though conservation of mass dictates that groundwater will typically only be a small component of total evapotranspiration across arid landscapes (i.e. recharge « evapotranspiration). In moderately humid regions, the fraction of precipitation that becomes groundwater substantially exceeds the fraction that becomes streamflow, and thus a substantial part of evapotranspiration must be supplied by groundwater. 


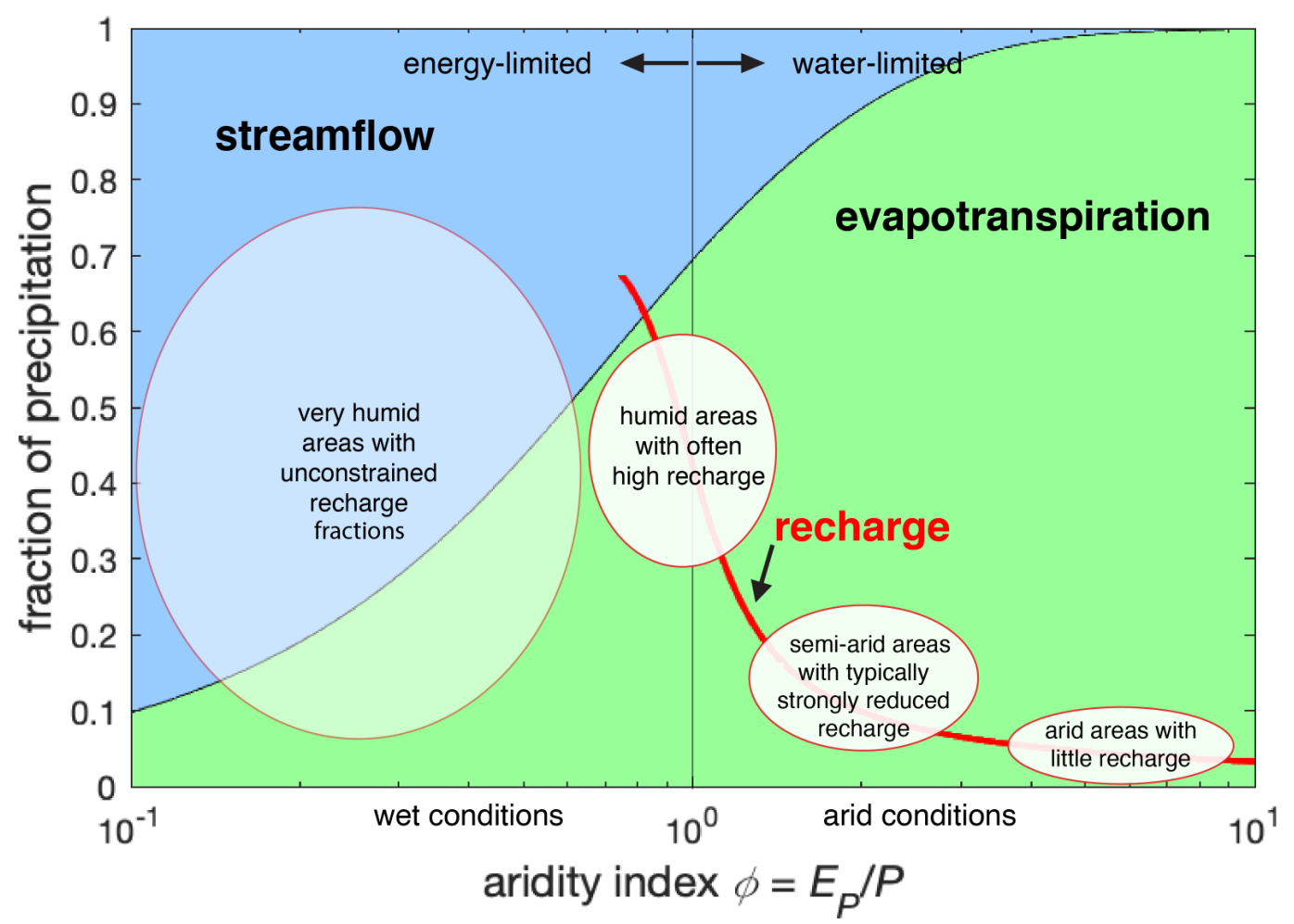

Fig 4. Conceptual representation of how groundwater recharge and its main fates vary with aridity. The partitioning of precipitation into streamflow and evapotranspiration follows the Budyko curve (Budyko, 1974).

A strong connection of groundwater with surface water and plant transpiration remains absent from most diagrams of the global water cycle (e.g., Oki \& Kanae, 2006; Abbott et al., 2019; Dorigo et al., 2021). Although such water cycle diagrams may not be intended as complete representations of the hydrological cycle, they often play an important role in teaching, research, and policymaking (Abbott et a., 2019). Therefore, we need to revise those diagrams by increasing the rate at which groundwater is being replenished and discharged, and strengthening the link of groundwater with incoming precipitation, surface waters, and vegetation.

The underrepresentation of groundwater as a key contributor to evapotranspiration and river flows seems pervasive in hydrological and land-surface models (e.g., Reinecke et a., 2021; de Graaf et al., 2015; Döll and Fiedler, 2008). Recharge is often considered a residual product of these simulations, accumulating the uncertainties of all other components of the budget (Reinecke et a., 2021), and models are not designed to treat groundwater recharge as a main source of streamflow and evapotranspiration. Preferential flow paths that can recharge groundwaters are important in virtually any landscape (Nimmo 2012; Beven and Germann, 
2013) and contribute disproportionally to fluxes such as recharge (e.g., Hartmann et al., 2017). These pathways are absent in most global models (e.g., Döll and Fiedler, 2008; de Graaf et al., 2015, 2019; Müller Schmied et al., 2021; Reinecke et al., 2021). Connections of groundwaters with streamflow and evapotranspiration could also be strengthened by including lateral groundwater flows (Maxwell \& Condon et al., 2016; Jasechko et al., 2021). Many of these lateral connections between surface water and groundwater will occur at scales smaller than the grid-cells of most models and thus require implicit sub-grid parameterizations (Fan et al., 2019). A strengthened groundwater connection to surface fluxes in these models is essential, given that these models are often the foundation of present-day environmental science and policymaking.

\section{Methods \\ Recharge data}

Recharge rates are obtained from a recent global synthesis of groundwater recharge rates of 5237 sites located across all continents but Antarctica (Moeck et al., 2020). Recharge is defined as the infiltrated water that reaches the water table. The compiled data primarily originate from tracer methods $(\sim 80 \%)$ but are also derived from water table fluctuations, water balance methods, lysimeters, heat tracers, and geophysical methods. This large variety of methods can affect estimated recharge rates at individual sites. The recharge estimation studies cover the period 1968 to 2018 . The mean recharge rate is $234 \mathrm{~mm}$ year ${ }^{-1}$, but over $40 \%$ of data points have rates between 0 - and $25-\mathrm{mm} \mathrm{year}^{-1}$ (median $51.3 \mathrm{~mm}$ year $^{-1}$ ). The dataset contains recharge rate estimates based on datasets that exceed at least one year to avoid bias in the rates due to seasonal effects and incomplete annual recharge values. Only naturally occurring recharge was considered, and recharge rates presumed to be affected by irrigation or managed aquifer recharge were omitted. Study sites where rivers and streams dominate the estimated recharge were also omitted. For more information on the data, we see Moeck et al. (2020) and references therein.

\section{Climate data}

We use temperature, aridity, precipitation, and potential evapotranspiration data from WorldClim (Fick \& Hijmans, 2017) and the global aridity and potential evapotranspiration database (Trabucco \& Zomer, 2009). We define the aridity index as the ratio of mean potential evapotranspiration to mean precipitation. Accordingly, high aridity index values 
reflect drier climates, whereas low values reflect more humid climates. Regions are classified as permafrost when the mean annual temperature is below $-1{ }^{\circ} \mathrm{C}$.

\section{Site data}

We also use 16 additional predictor variables collected by Moeck et al. (2020) for all groundwater recharge sites. These include mean precipitation (Fick \& Hijmans, 2017), mean potential evapotranspiration (Trabucco \& Zomer, 2009), temperature seasonality (Fick \& Hijmans, 2017), precipitation seasonality (Fick \& Hijmans, 2017), mean elevation (Danielson and Gesch (2011), depth to water table (Fan et al., 2013), depth to bedrock (Wei et al., 2017), slope (Yamazaki et al., 2017), topographic wetness index (Hengl, 2018b), the sand fraction (Hengl et al., 2017), silt fraction (Hengl et al., 2017), clay fraction (Hengl et al., 2017), lithology (Hengl, 2018c), landform (Hengl, 2018c), land use (Friedl et al., 2010), and vegetation (FAPAR) (Hengl, 2018a). We refer to Moeck et al. (2020) and references therein for more information on these data.

\section{Relationship between climate and recharge.}

A mathematical expression that describes the global pattern of climate aridity and groundwater recharge fractions is:

$$
\frac{R}{P}=\alpha\left(1-\frac{\ln \left(\phi^{\beta}+1\right)}{1+\ln \left(\phi^{\beta}+1\right)}\right)
$$

where $R$ is groundwater recharge $\left(\mathrm{mm} \mathrm{year}^{-1}\right), P$ is precipitation $\left(\mathrm{mm} \mathrm{year}^{-1}\right), \phi$ is aridity (dimensionless), defined as the ratio of potential evapotranspiration to precipitation $\left(E_{P} / P\right)$, and $\alpha$ (dimensionless) is a constant equating to the fraction of precipitation that becomes recharge for $\phi \rightarrow 0$ (i.e., humid conditions). $\beta$ is the characteristic exponent (dimensionless) of the aridity index. We calibrate the $\alpha$ and $\beta$ using a least absolute residuals fit. The sigmoidal equation was selected because it is among the simplest equation that enforces physically realistic upper and lower limits for recharge fraction. It closely follows the exponential decrease of recharge fraction with increasing aridity visible in global recharge data. We reorganize the equation to estimate total recharge $\left(\mathrm{mm} \mathrm{year}^{-1}\right)$ using global precipitation and aridity data (Fick \& Hijmans, 2017; Trabucco \& Zomer, 2009):

$$
R=P \cdot \alpha\left(1-\frac{\ln \left(\phi^{\beta}+1\right)}{1+\ln \left(\phi^{\beta}+1\right)}\right)
$$

The parsimony of this model could limit its predictive power, but making the model more complex does not substantially improve its predictive capacity. A split-sample test using $80 \%$ 
of the data for calibration and the remaining $20 \%$ for validation yields relatively narrow confidence bounds of the fitted parameters (95\% confidence bounds $\alpha=0.69-0.75, \beta=14.0$ - 16.2, not displayed), thus also subsets of the empirical data effectively constrain the relationship. The split-sample test also indicates the regional variation in groundwater recharge using Eq. 2 can be predicted with a much smaller bias (mean recharge bias $=8.9$ $\mathrm{mm} \cdot$ year $^{-1}$ ) than global hydrological models while explaining more of the site-to-site variability than most models (mean $\mathrm{R}^{2}=0.36$; Fig. S3). Considering an additional 16 site attributes and a Neural Network fit with Levenberg-Marquardt optimization only slightly reduces the overall bias in the predictions (mean recharge bias $=7.9 \mathrm{~mm} \cdot \mathrm{year}^{-1}$ ) and does not improve the explained site-to-site variability substantially (mean $\mathrm{R}^{2}=0.37$; Fig. S1). Thus, compared to more complex methods, predictions of groundwater recharge based on climate aridity appear effective despite excluding many other factors that potentially also affect groundwater recharge. We, therefore, opted to use the most straightforward approach in our main paper.

\section{Groundwater recharge estimates from global models}

We obtained recharge estimates from the PCR-GLOB hydrological model (de Graaf et al., 2015; 2019) and the WaterGAP Global Hydrology Model (Döll \& Fiedlier, 2008; Müller Schmied et al., 2021), and machine learning (Mohan et al., 2018). For the 5237 stations with recharge data, we compare the observed discharge with the simulated recharge (Fig. 3). The recharge values from the global hydrological models represent mean annual recharge over a timespan that ranges from the year 1960 to 2001 (Döll \& Fiedler, 2008), 1957 to 2002 (De Graaf et al., 2015), 1960 to 2010 (de Graaf et al., 2019) and 1901 to 2016 (Müller Schmied et al., 2021), respectively.

\section{References}

Abbott, B. W., Bishop, K., Zarnetske, J. P., Minaudo, C., Chapin, F. S., Krause, S., ... \& Pinay, G. (2019). Human domination of the global water cycle absent from depictions and perceptions. Nature Geoscience, 12(7), 533-540.

Alley, W. M., Healy, R. W., LaBaugh, J. W., \& Reilly, T. E. (2002). Flow and storage in groundwater systems. Science, 296(5575), 1985-1990.

Beven, K., and Germann, P. (2013), Macropores and water flow in soils revisited, Water Resources Research, 49, 3071- 3092. 
Berg, A., \& McColl, K. A. (2021). No projected global drylands expansion under greenhouse warming. Nature Climate Change, 11(4), 331-337.

Berghuijs, W. R., \& Kirchner, J. W. (2017). The relationship between contrasting ages of groundwater and streamflow. Geophysical Research Letters, 44, 8925-8935.

Budyko, M. I. (1974). Climate and life (508 pp.). New York, NY: Academic Press.

Crosbie, R. S., Peeters, L. J., Herron, N., McVicar, T. R., \& Herr, A. (2018). Estimating groundwater recharge and its associated uncertainty: Use of regression kriging and the chloride mass balance method. Journal of Hydrology, 561, 1063-1080.

Gee, G.W. and Hillel, D. (1988), Groundwater recharge in arid regions: Review and critique of estimation methods. Hydrological Processes, 2, 255-266.

de Graaf, I. E. M., Sutanudjaja, E. H., Van Beek, L. P. H., \& Bierkens, M. F. P. (2015). A high-resolution global-scale groundwater model. Hydrology and Earth System Sciences, $19(2), 823-837$.

de Graaf, I. E. M., Gleeson, T., van Beek, L. R., Sutanudjaja, E. H., \& Bierkens, M. F. (2019). Environmental flow limits to global groundwater pumping. Nature, 574(7776), 9094.

De Vries, J. J., \& Simmers, I. (2002). Groundwater recharge: an overview of processes and challenges. Hydrogeology Journal, 10(1), 5-17.

Döll, P., \& Fiedler, K. (2008). Global-scale modeling of groundwater recharge. Hydrology and Earth System Sciences, 12(3), 863-885.

Döll, P., Mueller Schmied, H., Schuh, C., Portmann, F. T., \& Eicker, A. (2014). Global-scale assessment of groundwater depletion and related groundwater abstractions: Combining hydrological modeling with information from well observations and GRACE satellites. Water Resources Research, 50(7), 5698-5720.

Dorigo, W., Dietrich, S., Aires, F., Brocca, L., Carter, S., Cretaux, J. F., ... \& Aich, V. (2021). Closing the water cycle from observations across scales: Where do we stand?. Bulletin of the American Meteorological Society, 1-95.

Evaristo, J., \& McDonnell, J. J. (2017). Prevalence and magnitude of groundwater use by vegetation: a global stable isotope meta-analysis. Scientific Reports, 7(1), 1-12.

Fan, Y. (2015). Groundwater in the Earth's critical zone: Relevance to large-scale patterns and processes. Water Resources Research, 51(5), 3052-3069.

Fan, Y., Miguez-Macho, G., Jobbágy, E. G., Jackson, R. B., \& Otero-Casal, C. (2017). Hydrologic regulation of plant rooting depth. Proceedings of the National Academy of Sciences, 114(40), 10572-10577. 
Fan, Y., Clark, M., Lawrence, D. M., Swenson, S., Band, L. E., Brantley, S. L., ... \& Yamazaki, D. (2019). Hillslope hydrology in global change research and Earth system modeling. Water Resources Research, 55(2), 1737-1772.

Fick, S. E. \& Hijmans, R. J. (2017). WorldClim 2: new 1-km spatial resolution climate surfaces for global land areas. International Journal of Climatology. 37, 4302-4315. Gleeson, T., Wada, Y., Bierkens, M. F., \& Van Beek, L. P. (2012). Water balance of global aquifers revealed by groundwater footprint. Nature, 488(7410), 197-200.

Gleeson, T., Befus, K. M., Jasechko, S., Luijendijk, E., \& Cardenas, M. B. (2016). The global volume and distribution of modern groundwater. Nature Geoscience, 9(2), 161-167. Gleeson, T., Cuthbert, M., Ferguson, G., Perrone, D. (2020). Global Groundwater Sustainability, Resources, and Systems in the Anthropocene. Annual Review of Earth and Planetary Sciences, 48, 431-463.

Hartmann, A., Gleeson, T., Wada, Y., \& Wagener, T. (2017). Enhanced groundwater recharge rates and altered recharge sensitivity to climate variability through subsurface heterogeneity. Proceedings of the National Academy of Sciences, 114(11), 2842-2847. Jasechko, S., Kirchner, J. W., Welker, J. M., \& McDonnell, J. J. (2016). Substantial proportion of global streamflow less than three months old. Nature Geoscience, 9(2), 126129.

Jasechko, S., Perrone, D., Befus, K. M., Cardenas, M. B., Ferguson, G., Gleeson, T., ... \& Kirchner, J. W. (2017). Global aquifers dominated by fossil groundwaters but wells vulnerable to modern contamination. Nature Geoscience, 10(6), 425-429. Jasechko, S., Seybold, H., Perrone, D., Fan, Y., \& Kirchner, J. W. (2021). Widespread potential loss of streamflow into underlying aquifers across the USA. Nature, 591(7850), 391-395.

Kirchner, J. W. (2003), A double paradox in catchment hydrology and geochemistry, Hydrological Processes, 17, 871-874.

Koirala, S., et al. (2017), Global distribution of groundwater-vegetation spatial covariation, Geophysical Research Letters, 44, 4134-4142.

Famiglietti, J. S. (2014). The global groundwater crisis. Nature Climate Change, 4(11), 945948.

Li, B., Rodell, M., Peters-Lidard, C., Erlingis, J., Kumar, S., \& Mocko, D. (2021).

Groundwater Recharge Estimated by Land Surface Models: An Evaluation in the Conterminous United States. Journal of Hydrometeorology, 22(2), 499-522. 
MacDonald, A. M., Lark, R. M., Taylor, R. G., Abiye, T., Fallas, H. C., Favreau, G., ... \& West, C. (2021). Mapping groundwater recharge in Africa from ground observations and implications for water security. Environmental Research Letters, 16(3), 034012.

Margat, J., \& Van der Gun, J. (2013). Groundwater around the world: a geographic synopsis. Crc Press.

Maxwell, R. M., \& Condon, L. E. (2016). Connections between groundwater flow and transpiration partitioning. Science, 353(6297), 377-380.

Moeck, C., Grech-Cumbo, N., Podgorski, J., Bretzler, A., Gurdak, J. J., Berg, M., \& Schirmer, M. (2020). A global-scale dataset of direct natural groundwater recharge rates: A review of variables, processes and relationships. Science of The Total Environment, 717, 137042.

Mohan, C., Western, A. W., Wei, Y., \& Saft, M. (2018). Predicting groundwater recharge for varying land cover and climate conditions-a global meta-study. Hydrology and Earth System Sciences, 22(5), 2689-2703.

Morris, B. L., Lawrence, A. R., Chilton, P. J., Adams, B., Cay- low, R. C. \& Klinck, B. A. (2003). Groundwater and its susceptibility to degradation: a global assessment of the problems and options for management. UNEP Early Warning \& Assessment Report Series RS. 03-3, Nairobi, Kenya.

Müller Schmied, H., Cáceres, D., Eisner, S., Flörke, M., Herbert, C., Niemann, C., ... \& Döll, P. (2021). The global water resources and use model WaterGAP v2. 2d: Model description and evaluation. Geoscientific Model Development, 14(2), 1037-1079.

Nimmo, J. R. (2012). Preferential flow occurs in unsaturated conditions. Hydrological Processes, 26(5), 786-789.

Obu, J., Westermann, S., Bartsch, A., Berdnikov, N., Christiansen, H. H., Dashtseren, A., ... \& Zou, D. (2019). Northern Hemisphere permafrost map based on TTOP modelling for 2000-2016 at 1 km2 scale. Earth-Science Reviews, 193, 299-316.

Oki, T., \& Kanae, S. (2006). Global hydrological cycles and world water resources. Science, 313(5790), 1068-1072.

Reinecke, R., Müller Schmied, H., Trautmann, T., Andersen, L. S., Burek, P., Flörke, M., ... \& Döll, P. (2021). Uncertainty of simulated groundwater recharge at different global warming levels: a global-scale multi-model ensemble study. Hydrology and Earth System Sciences, 25(2), 787-810. 
Rodell, M., Famiglietti, J. S., Wiese, D. N., Reager, J. T., Beaudoing, H. K., Landerer, F. W., \& Lo, M. H. (2018). Emerging trends in global freshwater availability. Nature, 557(7707), 651-659.

Sutanudjaja, E. H., Beek, R. V., Wanders, N., Wada, Y., Bosmans, J. H., Drost, N., ... \& Bierkens, M. F. (2018). PCR-GLOBWB 2: a 5 arcmin global hydrological and water resources model. Geoscientific Model Development, 11(6), 2429-2453.

Scanlon, B. R., Keese, K. E., Flint, A. L., Flint, L. E., Gaye, C. B., Edmunds, W. M., \& Simmers, I. (2006). Global synthesis of groundwater recharge in semiarid and arid regions. Hydrological Processes: An International Journal, 20(15), 3335-3370.

Taylor, R. G., Todd, M. C., Kongola, L., Maurice, L., Nahozya, E., Sanga, H., \& MacDonald, A. M. (2013). Evidence of the dependence of groundwater resources on extreme rainfall in East Africa. Nature Climate Change, 3(4), 374-378

Trabucco, A. \& Zomer, R. J. Global Aridity and PET Database (CGIAR Consortium for Spatial Information, 2009); https://cgiarcsi.community/data/global-aridity-and-pet-database/ Walvoord, M. A., \& Kurylyk, B. L. (2016). Hydrologic impacts of thawing permafrost-A review. Vadose Zone Journal, 15(6).

\section{Methods references}

Danielson, J.J., Gesch, D.B., (2011). Global Multi-resolution Terrain Elevation Data 2010 (GMTED2010). US Geological Survey.

Fan, Y., Li, H., \& Miguez-Macho, G. (2013). Global patterns of groundwater table depth. Science, 339(6122), 940-943.

Friedl, M.A., Sulla-Menashe, D., Tan, B., Schneider, A., Ramankutty, N., Sibley, A., Huang, X., (2010). MODIS Collection 5 global land cover: algorithm refinements and characterization of new datasets. Remote Sensing of Environment. 114, 168-182. Hengl, T., (2018a) Fraction of Absorbed Photosynthetically Active Radiation (FAPAR) at 250m Monthly for Period 2014-2017 Based on COPERNICUS Land Products (Version 1.0) ([Data set]. Zenodo doi:105281/zenodo1450337).

Hengl, T., (2018b). Global DEM Derivatives at $250 \mathrm{~m}, 1 \mathrm{~km}$ and $2 \mathrm{~km}$ Based on the MERIT DEM (Version 1.0) ([Data set]. Zenodo doi:105281/zenodo1447210).

Hengl, T., (2018c). Global Landform and Lithology Class at $250 \mathrm{~m}$ Based on the USGS Global Ecosystem Map (Version 1.0) ([Data set]. Zenodo doi:105281/zenodo1464846). 
Yamazaki, D., Ikeshima, D., Tawatari, R., Yamaguchi, T., O'Loughlin, F., Neal, J.C., Sampson, C.C., Kanae, S., Bates, P. D. (2017). A high-accuracy map of global terrain elevations. Geophysical Research Letters, 44, 5844-5853.

Wei, S.G., Hengl, T., de Jesus, J.M., Yuan, H., Dai, Y.J. (2017). Mapping the global depth to bedrock for land surface modeling. Journal of Advances in Modeling Earth Systems, 9, 6588. 

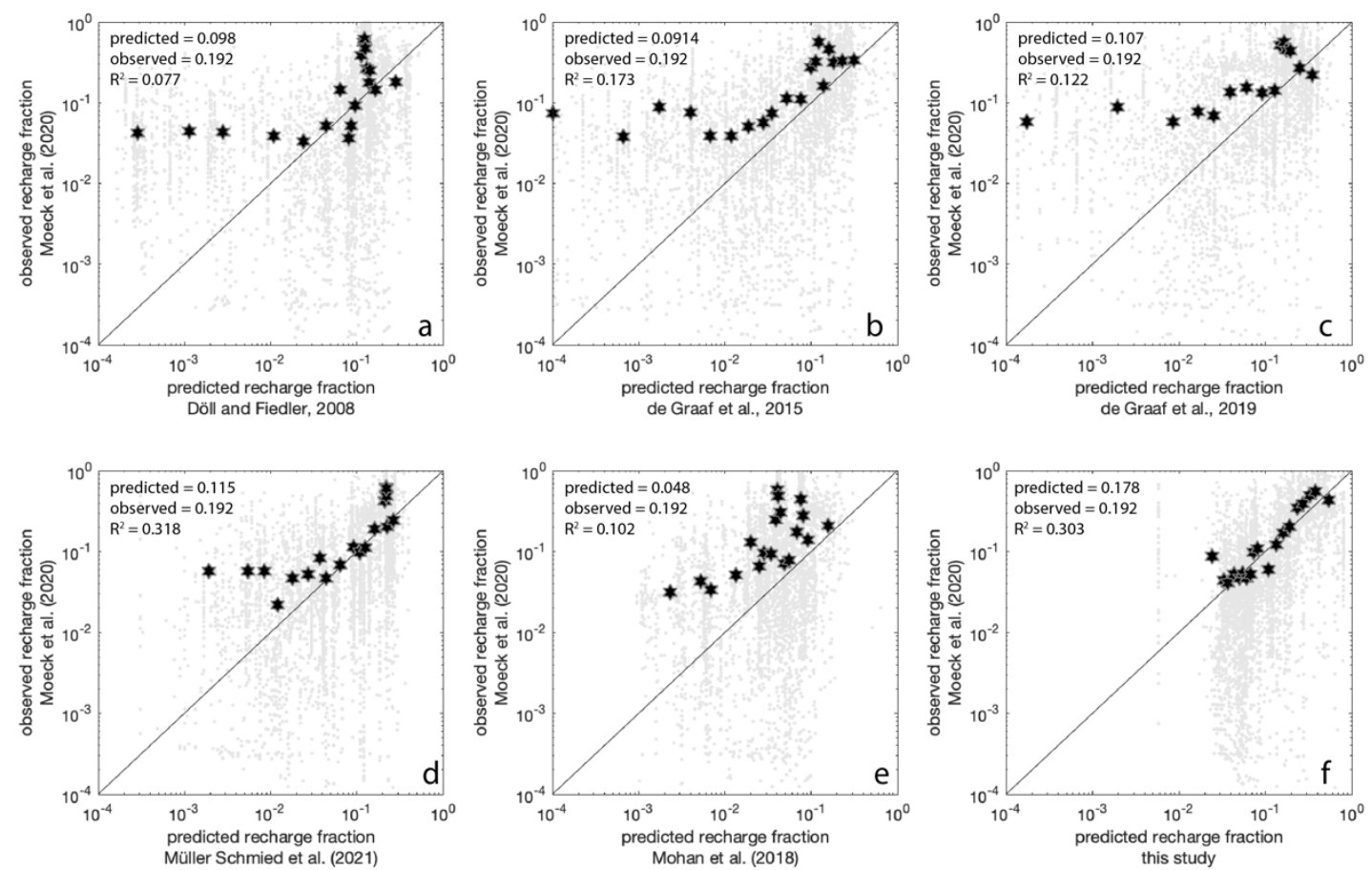

Fig. S1. Recharge fractions in models and observations. Recharge fractions (the ratio of recharge to precipitation) at the 5327 observation sites (Moeck et al., 2020) are estimated with substantial biases by PCRGLOB (de Graaf et al., 2015, 2019) (b, c) WaterGAP (Döll and Fiedler, 2008; Müller Schmied et al., 2021) (b, d) and machine learning (Mohan et al., 2018) compared to the simple sigmoid function (this paper) (f). The global hydrological models tend to underestimate the recharge fractions by over a factor of 2 for the observation sites. The recharge fractions are also binned into 25 bins for the plots, each containing $4 \%$ of the data. 

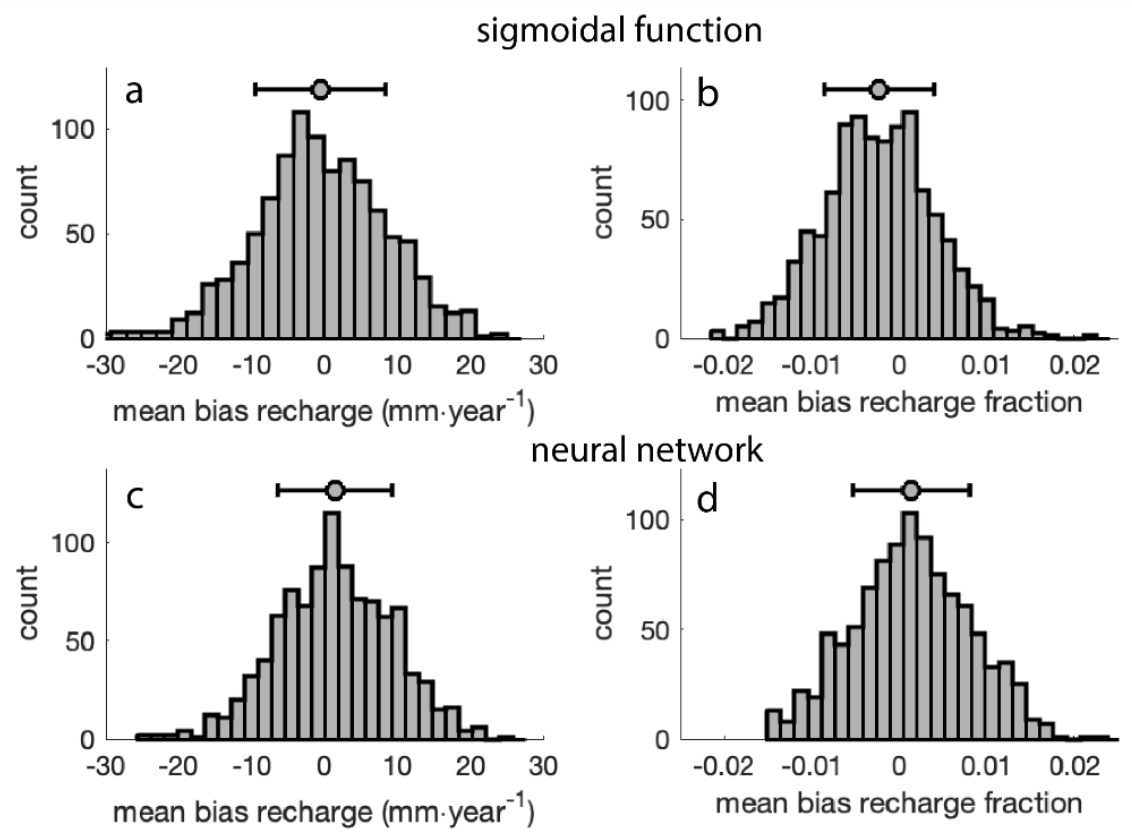

Fig. S2. Mean error in predictions of groundwater recharge rates and recharge fractions at the validation sites. Histograms show the mean error in the prediction of groundwater recharge fractions (long-term recharge divided by long-term precipitation) using the sigmoidal function presented in this paper ( $a, b)$ and a neural network fitting approach (c, d) for 1000 repetitions of a split-sample test where $80 \%$ of the data from the 5237 recharge sites are used for calibration and the remaining $20 \%$ for validation. The marker indicates the mean of the values, and the whiskers indicate the standard deviation. 

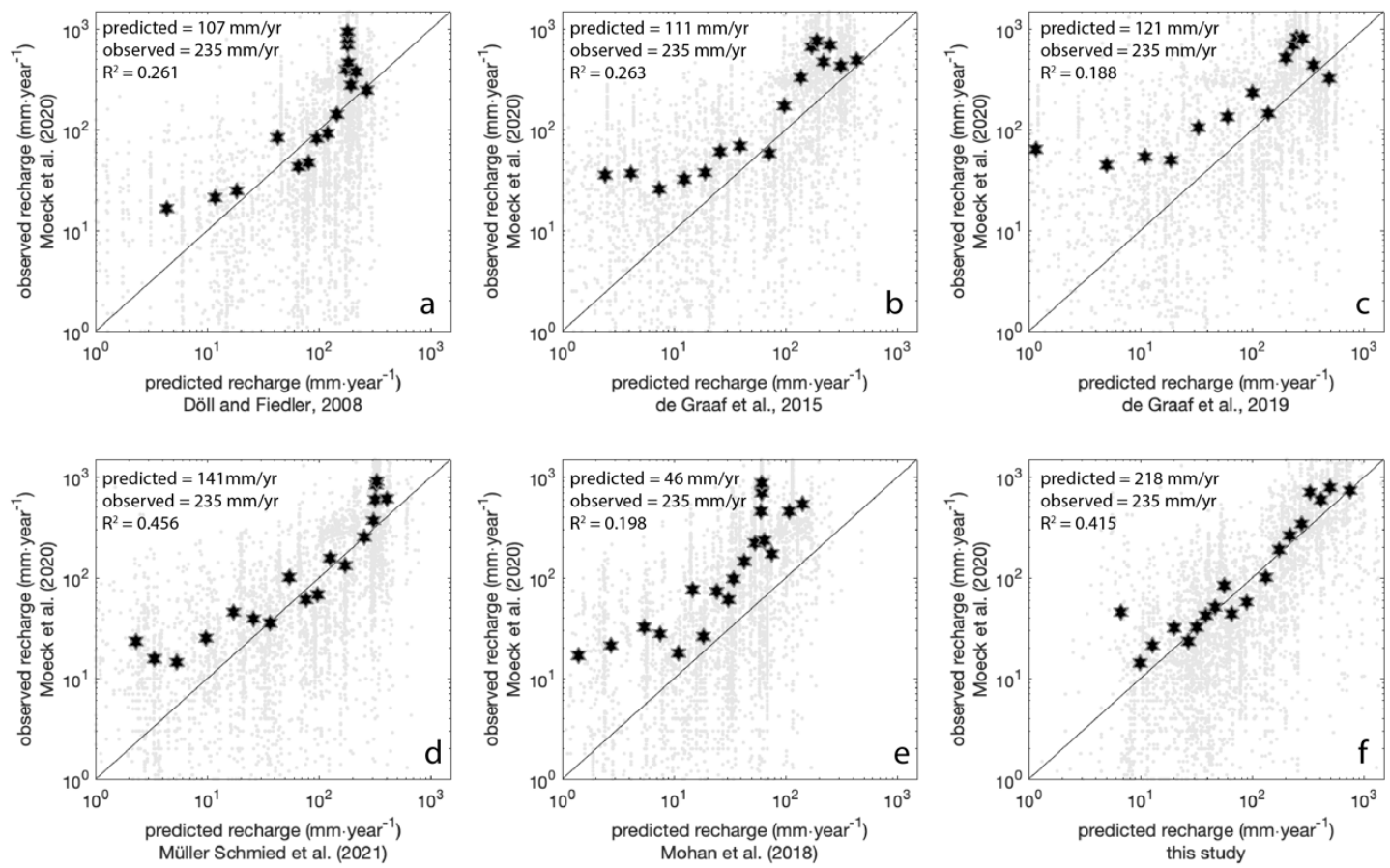

Fig. S3. Comparison of predicted versus observed recharge for several global recharge predictions.

Recharge predicted by global models such as PCR-GLOB (de Graaf et al., 2015; 2019), WATER-GAP (Döll et al., 2008; Müller Schmied et al., 2021), and machine learning (Mohan et al., 2018) (a-e) is systematically lower than recharge of the 5237 observation sites. The previous estimates (a-e) underestimate recharge by more than $50 \%$ compared to the recharge measurement (Moeck et al., 2020). Using the sigmoid function (f) removes this bias and produces an overall average recharge of a very similar magnitude as global recharge estimates (f). The recharge rates are also binned into 25 bins for the plots, each containing $4 \%$ of the data. 